\title{
Analysis of Distribution Patterns in Mapping Cirebon Internet Service Facilities Using NNA Algorithm Based on Geographic Information Systems
}

\author{
Chairun Nas ${ }^{1}$, Nursaka Putra ${ }^{2}$, Ilwan Syafrinal ${ }^{3}$ \\ ${ }^{1,2,3}$ Fakultas Teknologi Informasi, Universitas Catur Insan Cendekia, Cirebon, Indonesia
}

\begin{tabular}{l} 
Article Info \\
\hline Article history: \\
Received 0625,2021 \\
Revised 1120,2021 \\
Accepted 12 10, 2021
\end{tabular}

\section{Keywords:}

Mapping

Internet

NNA Algorithm

GIS

\begin{abstract}
Cirebon city moves continually to become Smart City by making technology to public service. One form of technology to public service to is by providing internet facilities for public or for community. Currently there are several internet facility services for public, but these services are only available at certain location points and are not spread evenly. Apart from that, the government has difficulty in determining the right location points to serve as public internet service facilities. The purpose of this research is to analyze the pattern of distribution of internet facilities location points so that they can be mapped digitally using Geographic Information Systems. In this research, the data used were 49 object data points for location of internet facilities in Cirebon. Furthermore, the data will be analyzed using the Nearest Neighbor Analysis (NNA) method to determine the distribution pattern of internet facility location points. Based on the resulting distribution pattern, it can be implemented into digital mapping using Geographic Information Systems. So the Geographic Information System can help the government in making decisions, and for the public to find out the location points of internet facilities in Cirebon.
\end{abstract}

This is an open access article under the CC BY-SA license.

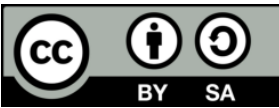

\author{
Corresponding Author: \\ Chairun Nas \\ Fakultas Teknologi Informasi \\ Universitas Catur Insan Cendekia \\ Cirebon, Indonesia \\ Email: chairun.nas@cic.ac.id \\ (C) Chairun Nas, Nursaka Putra, Ilwan Syafrinal 2021
}

\section{Introduction}

As the city has been growing rapidly, Cirebon strives to continue in advancing in its development. By using existing resources and current technological advances, government of Cirebon aspires to make Cirebon a Smart City. The purpose of building Smart City is to improve the quality of life by using urban information and technology to increase service efficiency and meet the needs of citizens [1]. One of the services improved by government of Cirebon is services in public open spaces. Services in public open spaces in Cirebon are built for the needs of city people of Cirebon itself. One of the public open space services provided by the Cirebon city government is internet service facilities.

Internet is computer network that can connect and can communicate each other. Based on science, internet is a large library in millions information or data in the form of electronic media [2]. Internet service facilities are facilities in the form of internet services that can be access free for public, and can be access at internet facilities points have been provided by government. However, information regarding the location points of internet services in public spaces in Cirebon is still too minimal because the distribution of the location 
of internet service facilities in Cirebon is still random. This is due to the fact that Cirebon government still has difficulty in determining the location points for internet service facilities.

To overcome these problems, it is necessary to analyze the location points of internet facilities using the Nearest Neighbor Analysis (NNA) algorithm. The NNA algorithm or also called nearest neighbor analysis is an algorithm that explains the distribution pattern of location points by accounting of the distance between points, the number of distribution points and area [3]. The result of NNA algorithm is the distribution pattern of the location points of internet facilities that can be implemented in the form of mapping. Mapping is a form of graphical communication between map makers and map users which consists of collection of data and information according to their location in two dimensions [4]. With mapping result, a geographic information system can be built that provides information about location points of internet facilities in Cirebon.

Geographic Information System (GIS) is computer-based system was used to manipulate and process geographic data or geographic information. GIS is designed to collect, store and analyze objects and phenomena where geographical location is an important or critical characteristic to be analyzed [5]. Through GIS, it can visualize the real-world condition into an image, GIS also helps in understanding the concepts of natural phenomena related to geographical and spatial aspects, to make easy in planning and managing decisions according to the needy [6].

Using geographic information system and object data of internet service facilities that have been analyzed using NNA algorithm, it can assist the government in making decisions to determine the location of internet facilities. Apart from that, it also provides information to public about location of internet facilities in Cirebon.

\section{Research Method}

The research methodology will be carried out in this research consists of several steps, as for these steps can be seen in Figure 1 below:

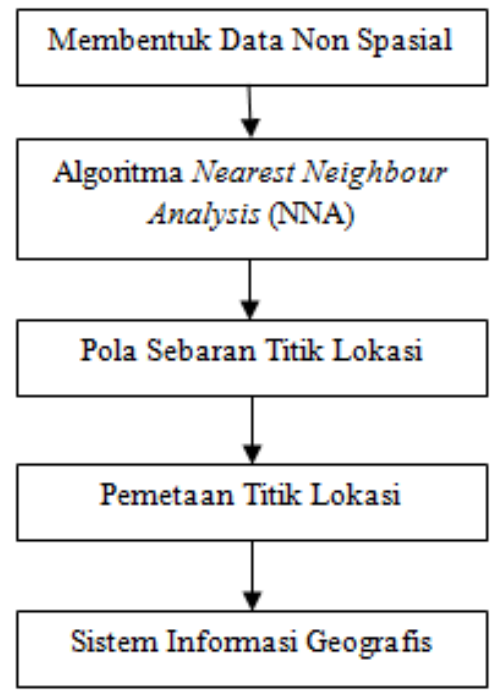

Figure 1. Research Methodoly

Based on the research methodology above, each stage of the research can be explained as follows:

2.1. Non-Spatial Data

Non-spatial data is presented data in the form of tables containing descriptive information of geographical elements such as names, addresses, area and others owned by objects in spatial data [7]. Nonspatial data in this research can be seen in Table 1 below:

Table 1. Object Data for Internet Facility Locations

Table 1. Object of location point internet fasilities

\begin{tabular}{clccc}
\hline \multirow{2}{*}{ No } & \multicolumn{1}{c}{ Object } & \multirow{2}{*}{ Sub-District } & \multicolumn{2}{c}{ Coordinate Points } \\
\cline { 3 - 4 } & & & Latitude & Longitude \\
\hline 1 & Kelurahan Kalijaga & Harjamukti & -6.757469 & 108.547029 \\
2 & BAZNAS Kota Ciebon & Harjamukti & -6.741615 & 108.546069 \\
3 & Baperkam RW.19 Permata Asih & Harjamukti & -6.755608 & 108.55589 \\
4 & Alun Alun Kejaksan & Kejaksan & -6.709696 & 108.559205 \\
5 & Balai Kota Cirebon & Kejaksan & -6.707068 & 108.557806 \\
6 & Islamic Center Masjid At-taqwa & Kejaksan & -6.7101464 & 108.558564 \\
7 & Sentra PKL Stadion Bima & Kesambi & -6.732092 & 108.533575 \\
\hline
\end{tabular}




$\begin{array}{cl}8 & \text { Area Parkir Patung Bima } \\ 9 & \text { Gedung Kesenian Rarasantang } \\ 10 & \text { RS Pelabuhan Cirebon } \\ 11 & \text { Baperkam RW 02 Mandalangan } \\ 12 & \text { Baperkam RW 09 Kesunean Selatan } \\ 13 & \text { Kantor Telkom Kota Cirebon } \\ 14 & \text { Baperkam RW 04 Pegajahan Utara } \\ 15 & \text { Baperkam RW 10 Kanoman Utara } \\ \text { n.. } & \quad \ldots \ldots \ldots . . . \\ 49 & \text { Baperkam RW 02 Nusantara }\end{array}$

\begin{tabular}{ccc} 
Kesambi & -6.729424 & 108.536867 \\
Kesambi & -6.7296392 & 108.537032 \\
Lemahwungkuk & -6.7134449 & 108.567341 \\
Lemahwungkuk & -6.728290 & 108.57004 \\
Lemahwungkuk & -6.727741 & 108.57756 \\
Pekalipan & -6.7416150 & 108.546069 \\
Pekalipan & -6.726010 & 108.56862 \\
Pekalipan & -6.722114 & 108.56663 \\
$\ldots \ldots \ldots \ldots .$. & $\ldots \ldots \ldots \ldots \ldots \ldots \ldots \ldots$ \\
Harjamukti & -6.762796 & $\ldots \ldots \ldots \ldots \ldots$ \\
\hline
\end{tabular}

Based on non-spatial data above, the next step is to analyze data using NNA algorithm to find out the distribution pattern of location of internet facilities in Cirebon.

\subsection{Nearest Neighbor Analysis (NNA) Algorithm}

NNA algorithm aims to analyze non-spatial data to obtain pattern of point distribution for internet service facilities. The results of NNA algorithm are in the form of index (T) of the distribution pattern, where index (T) can be categorized into 4 types of distribution, namely [8]:

a. T value from $0-0.7$ : is clustered or empty distribution pattern (Cluster Pattern).

b. T value from $0.8-1.3$ : is pattern of random distribution or uneven distribution (Random Pattern)

c. T value from 1.4 to 2.1 : is uniform distribution pattern (Uniform Pattern).

d. T value $>2.1:$ is incomparable pattern of distribution with area (Incomparable Pattern) follows [8]:

To know the distribution pattern, there are steps in NNA algorithm to obtain the distribution pattern as

1) Determine the number of facility points, the distance between facility points and width area of facility location.

2) Determine the average distance of one point with the nearest neighbor, can use the following formula:

$J u=\frac{J a}{j t}$

Inf :

$J u=$ Average distance between one point with the nearest neighbor

$J a=$ Total of distance every location points

$J t=$ Total point

3) Determine the average distance if the number of points has random pattern, it can use the following formula:

$$
\begin{gathered}
P=\frac{J t}{L} \\
J h=\frac{1}{2 \sqrt{P}}
\end{gathered}
$$

Inf :

$P=$ Density point in kilometres

$L=$ Width of area

$J h=$ Average distances was obtained if point total random pattern

4) Determine index of the nearest neighbor spread

$$
T=\frac{J u}{J h}
$$

Based on NNA algorithm process above, then an analysis of non-spatial data that has been obtained into algorithm. The first step is to determine the total of sub-district internet facility points and the distance between these points which can be seen in Table 2 below:

Table 2. Per sub-district data 


\begin{tabular}{clccc}
\hline No & \multicolumn{1}{c}{ Sub-district } & Width & $\begin{array}{c}\text { Total of nearest neighbor } \\
\text { distance }\end{array}$ & Total point \\
\hline 1 & Kecamatan Kejaksan & $3,61 \mathrm{Km}^{2}$ & $4,195 \mathrm{Km}$ & 9 Titik \\
2 & Kecamatan Kesambi & $8,06 \mathrm{Km}^{2}$ & $9,835 \mathrm{Km}$ & 14 Titik \\
3 & Kecamatan Pekalipan & $1,56 \mathrm{Km}^{2}$ & $2,006 \mathrm{Km}$ & 5 Titik \\
4 & Kecamatan Lemahwungkuk & $6,53 \mathrm{Km}^{2}$ & $2,898 \mathrm{Km}$ & 5 Titik \\
5 & Kecamatan Harjamukti & $17,62 \mathrm{Km}^{2}$ & $9,625 \mathrm{Km}$ & 16 Titik \\
\hline
\end{tabular}

The total of distance of nearest neighbor point is obtained from total of distances from every point was calculated using Google Maps with distance taken based on straight line between points. Then, the value of average distance of one point with nearest neighbor can be determined which can be seen in Table 3 below:

Example :

JuKejaksan $=\frac{\text { Ja Kejaksan }}{\text { JtKejaksan }} \rightarrow \quad$ Ju Kejaksan $=\frac{4,195}{9}=\mathbf{0 , 4 6 6 1}$

Table 3. Average distance one point with nearest neighbor

\begin{tabular}{clccc}
\hline No & \multicolumn{1}{c}{ Sub-district } & $J a$ & $J t$ & $J u$ \\
\hline 1 & Kecamatan Kejaksan & $4,195 \mathrm{Km}$ & 9 Titik & 0,4661 \\
2 & Kecamatan Kesambi & $9,835 \mathrm{Km}$ & 14 Titik & 0,5453 \\
3 & Kecamatan Pekalipan & $2,006 \mathrm{Km}$ & 5 Titik & 0,4012 \\
4 & Kecamatan Lemahwungkuk & $2,898 \mathrm{Km}$ & 5 Titik & 0,5796 \\
5 & Kecamatan Harjamukti & $9,625 \mathrm{Km}$ & 16 Titik & 0,6015 \\
\hline
\end{tabular}

After obtaining the average distance value of one point with nearest neighbor, then determine average distance value if total of points has random pattern, which can be seen in Table 4 below:

Example :

$P$ Kejaksan $=\frac{J \text { Kejaksan }}{\text { L Kejaksan }} \quad \rightarrow \quad P$ Kejaksan $=\frac{9}{3,61}=\mathbf{2 , 4 9 3 0}$

Jh Kejaksan $=\frac{1}{2 \sqrt{\text { P Kejaksaan }}} \quad \rightarrow \quad$ Jh Kejaksan $=\frac{1}{2 \sqrt{2,4930}}=\mathbf{0 , 3 1 6 6}$

Table 4. Average distance obtained if random pattern point total

\begin{tabular}{clcccc}
\hline No & \multicolumn{1}{c}{ Sub-district } & $L$ & $J t$ & $P$ & \multicolumn{1}{c}{$J h$} \\
\hline 1 & Kecamatan Kejaksan & $3,61 \mathrm{Km}^{2}$ & 9 Titik & 2,4930 & 0,3166 \\
2 & Kecamatan Kesambi & $8,06 \mathrm{Km}^{2}$ & 14 Titik & 1,7369 & 0,3793 \\
3 & Kecamatan Pekalipan & $1,56 \mathrm{Km}^{2}$ & 5 Titik & 3,2051 & 0,2792 \\
4 & Kecamatan Lemahwungkuk & $6,53 \mathrm{Km}^{2}$ & 5 Titik & 0,7656 & 0,5714 \\
5 & Kecamatan Harjamukti & $17,62 \mathrm{Km}^{2}$ & 16 Titik & 0,9080 & 0,5247 \\
\hline
\end{tabular}

After obtaining the average distance value if total of points has random pattern, the last step is to determine index value and the distribution pattern of the location points which can be seen in Table 5 below:

Example :

TKejaksan $=\frac{\text { JuKejaksan }}{\text { Jh Kejaksan }} \quad \rightarrow \quad$ T Kejaksan $=\frac{0,4661}{0,3166}=\mathbf{1 , 4 7 1 9}$

Table 5. Indeks $(T)$ data and distribution pattern of location points

\begin{tabular}{clcccc}
\hline No & \multicolumn{1}{c}{ Sub-district } & $J u$ & $J h$ & $T$ & Distribution pattern \\
\hline 1 & Kecamatan Kejaksan & 0,4661 & 0,3166 & 1,4719 & Uniform Pattern \\
2 & Kecamatan Kesambi & 0,5453 & 0,3793 & 1,4374 & Uniform Pattern \\
3 & Kecamatan Pekalipan & 0,4012 & 0,2792 & 1,4365 & Uniform Pattern \\
4 & Kecamatan Lemahwungkuk & 0,5796 & 0,5714 & 1,0143 & Random Pattern \\
5 & Kecamatan Harjamukti & 0,6015 & 0,5247 & 1,1464 & Random Pattern \\
\hline
\end{tabular}

Based on the results of the distribution pattern index (T) obtained using NNA algorithm, it is obtained 3 districts have spread even distribution pattern and 2 other districts have random distribution pattern. The 
researcher can conclude, with location points that have been obtained, $60 \%$ of location points for internet facilities in Cirebon have been spread evenly.

2.3. Mapping and Determinating of Location Points

In this research, the mapping was carried out in Cirebon with mapping based on spatial data had been obtained. Mapping is done using GeoJSON. GeoJSON is an encoding format for various geographic data structures based on JSON (Javascript Object Notation) format. GeoJSON supports several types of geometry such as Point, LineString, Polygon, and other multi geometry types [9]. The results of mapping using GeoJSON can be seen in Figure 2 below:
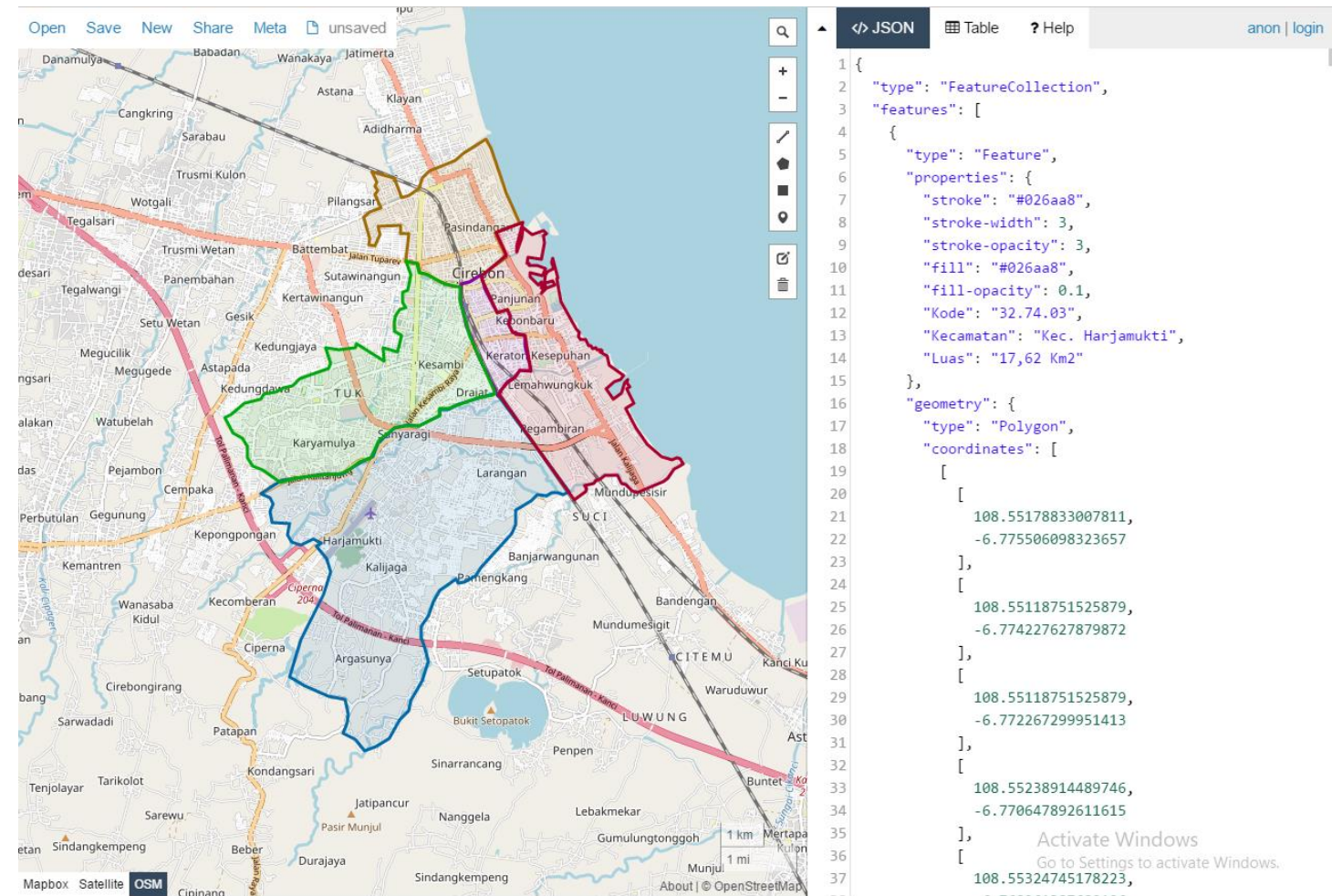

Figure 2. Mapping Cirebon Based on sub-district area

After mapping, the process of determining location of the object of internet service facilities is carried out into built mapping. Determination of object location using GeoJSON with the results of determining location point can be seen in Figure 3 below: 


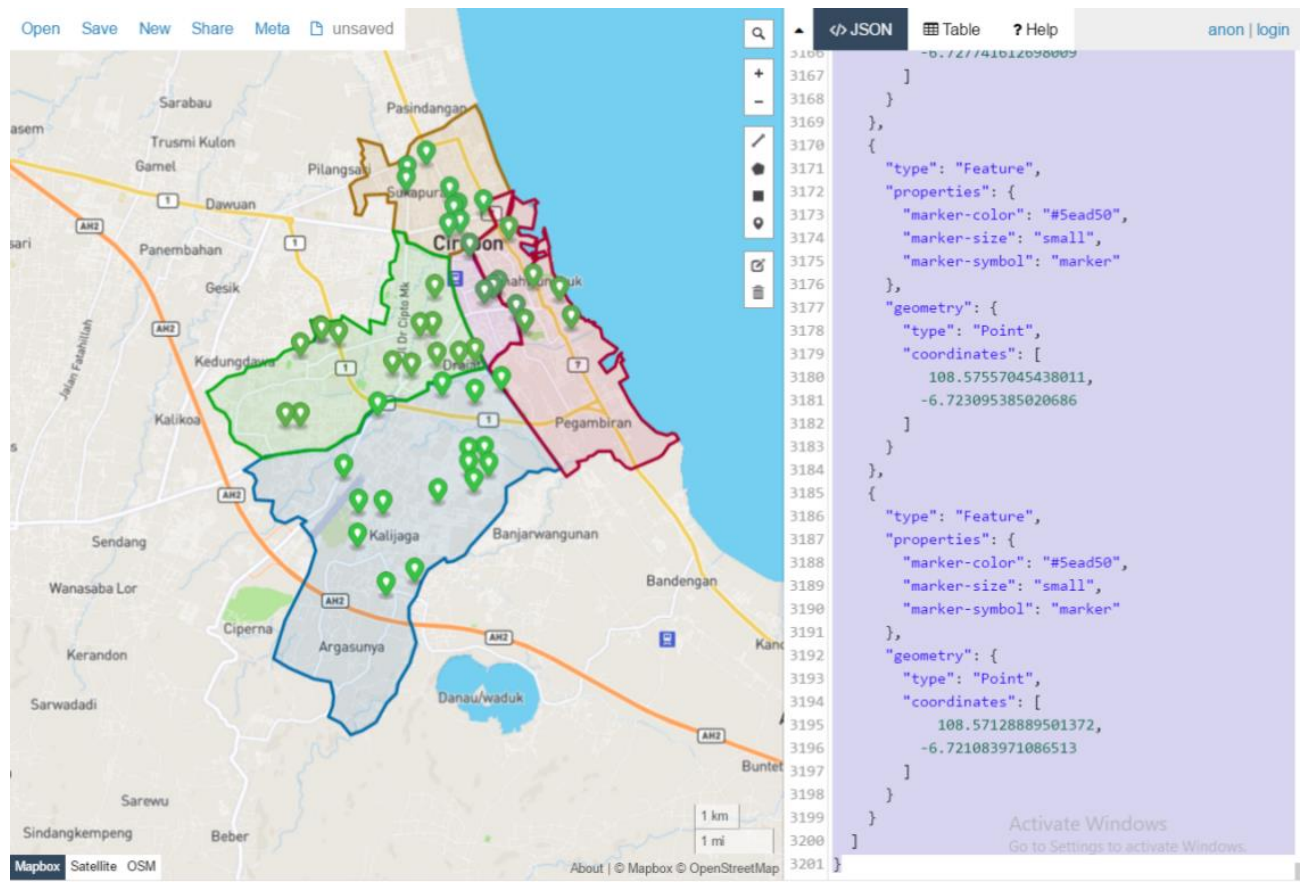

Figure 3. Mapping Cirebon Based on sub-district area

Based on the results of mapping and determining the location of internet facilities that have been made, the mapping will be implemented into Geographic Information System.

\subsection{Geographic Information System}

Before building a system, in this research, a system flow design was carried out using Unified Modeling Language (UML). UML is a tool for visualizing and documenting the results of analysis and design which contains syntax for visually modeling the system [10]. The UML used are Use Case Diagrams, Class Diagrams and Activity Diagrams. The system model design can be seen as follows:

\section{a. Use Case Diagrams}

Use Case diagram is a modeling to describe behavior of a system user (actor) toward a system [11]. Geographic Information System will be built consists of 2 parts, namely the Frontend which is used by general users, and the Backend which is used by administrators to manage data. The design of Use Case Diagram model can be seen in Figure 4 and Figure 5 below:

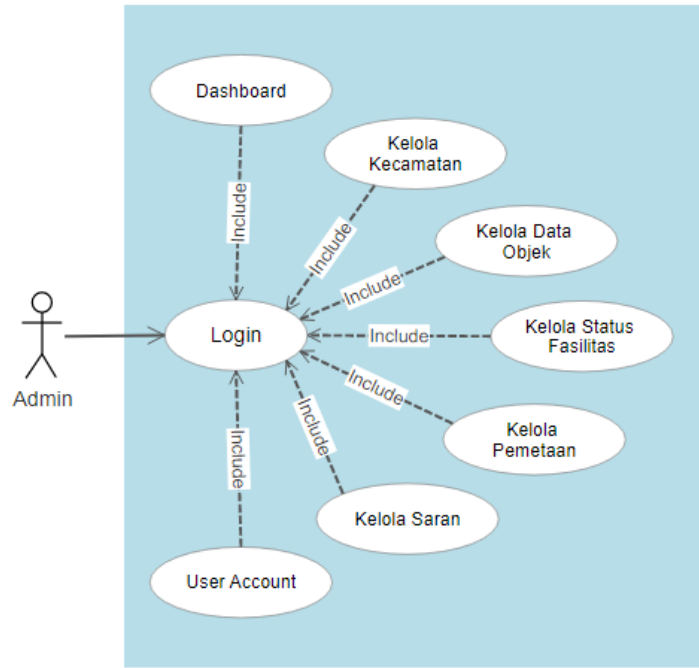

Figure 4. Use Case Design of Admin

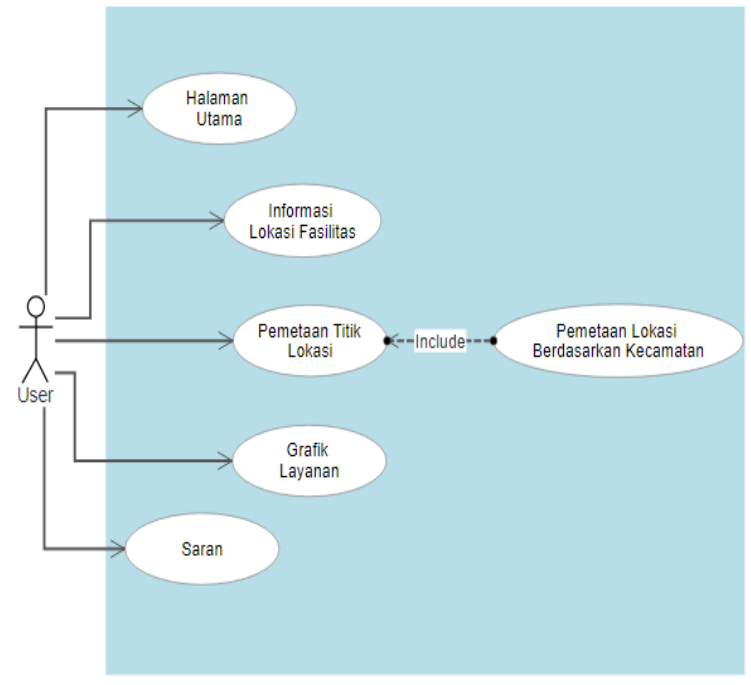

Figure 5. Use Case Design of User 
b. Class Diagram

Class Diagram describes data structure of system in terms of defining classes that will be useful in system development where each class has attributes and operators [12]. Class diagrams also explain the relationship every classes including classes, attributes and operations. Class Diagram design can be seen in Figure 6 below:

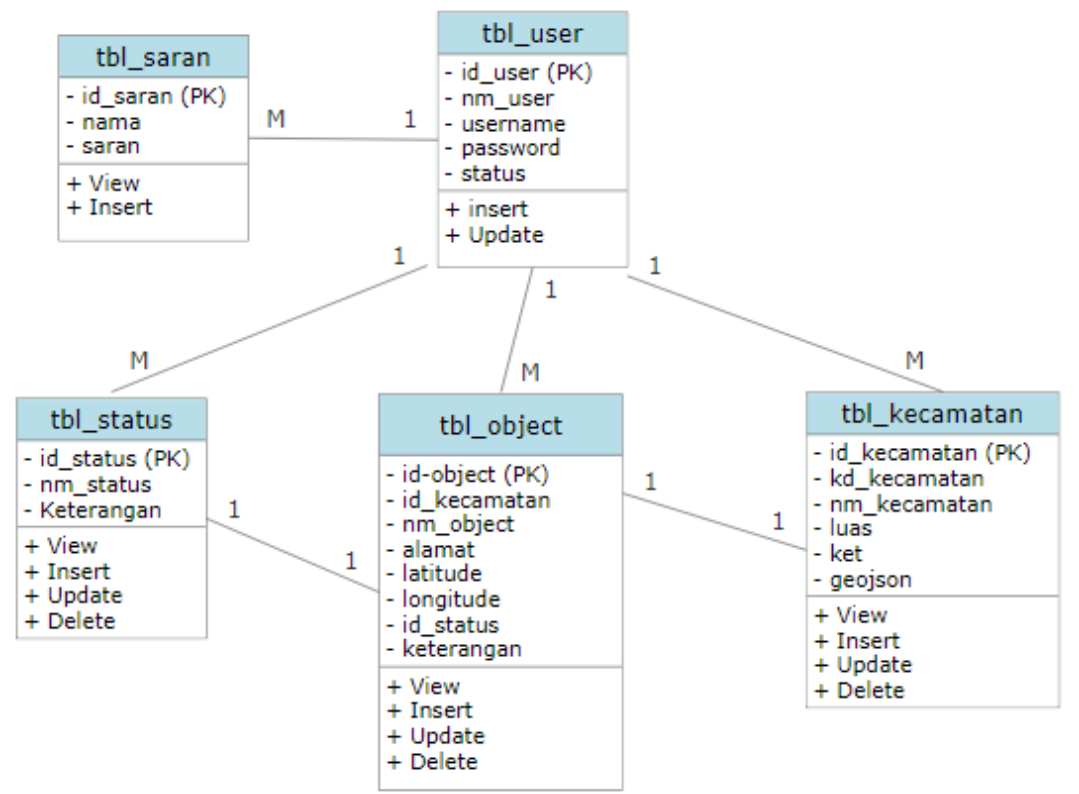

Figure 6. Class Diagram Geographic Information System

c. Activity Diagram

activity diagram is description of various flow of activities in the system starting from the initial flow process, decission, activity and how a system ends from all parallel processes [13]. Activity Diagram describes the process model that occurs in a system. The activity diagram design for general users and administrators can be seen in Figure 7 and Figure 8 as follows:

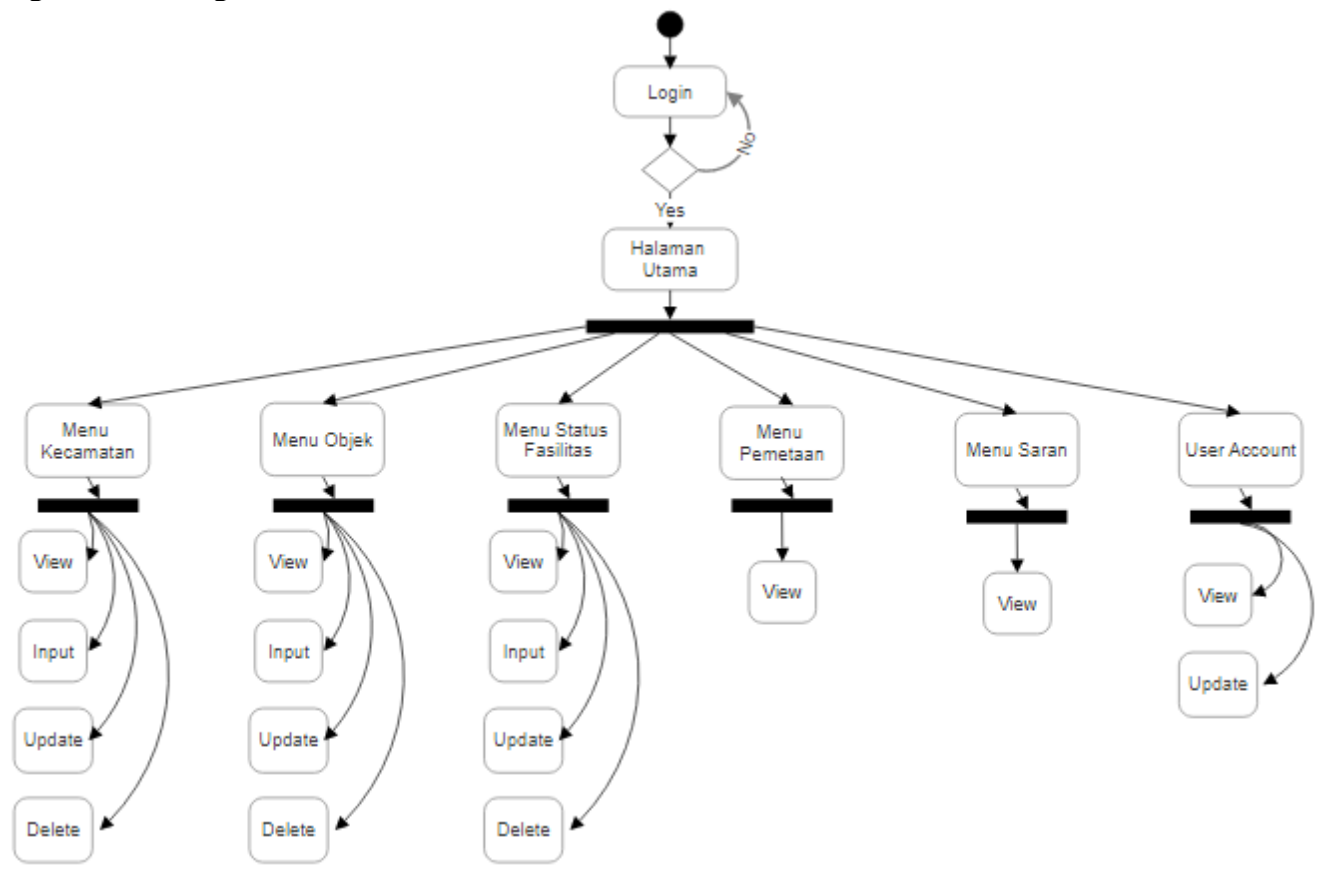

Figure 7. Activity Diagram Design of User 


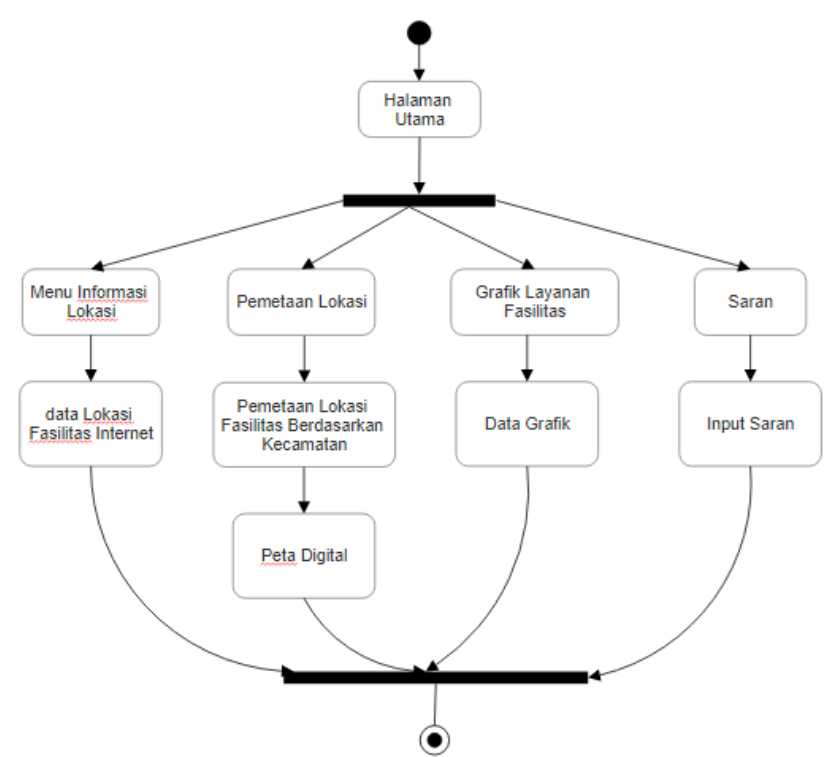

Figure 8. Activity Diagram Design of Admin

After designing using UML, then website-based geographic information system was built using the PHP programming language.

\section{b. Result and Discussion}

Berdasarkan metodologi penelitian yang telah dijelaskan diatas, maka langkah selanjutnya adalah membangun SIG berbasiskan website. Pemetaan yang telah dibuat akan di implementasikan ke dalam SIG dengan menggunakan Leaflet JS. Leafleat JS adalah merupakan library javascript open source yang berguna untuk membangun sebuah peta interaktif berbasis web ataupun mobile [14]. Leaflet JS sendiri support dengan platform mobile dan platform dekstop, HTML 5 dan CSS 3 serta OpenLayer dan Google Maps API. Saat ini Leaflet JS sendiri merupakan library javascript untuk membangun aplikasi peta yang sangat populer saat ini. Adapun hasil dari sistem yang dibangun dapat dilihat seperti berikut.

Based on the research methodology described above, the next step is to build website-based GIS. The mapping that has been created will be implemented into GIS using Leaflet JS. Leafleat JS is open source javascript library that is useful for building an interactive map based on web or mobile [14]. Leaflet JS supports mobile platforms and desktop platforms, HTML 5 and CSS 3, and OpenLayer and Google Maps API. Currently, Leaflet JS is javascript library for building popular map applications. The results of the system built can be seen as follows.

\subsection{Login Page And Administrator Main Page}

Login page is a page used by administrators to enter the system, the administrator main page is used by administrators to access the menus contained in Backend system. The display of login page and main administrator page can be seen in Figure 9 and Figure 10 as follows:

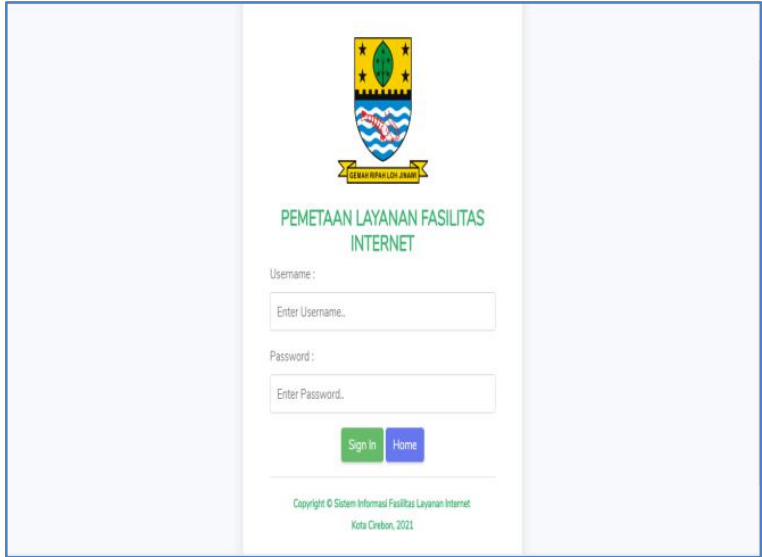

Figure 9. Admin Login Page

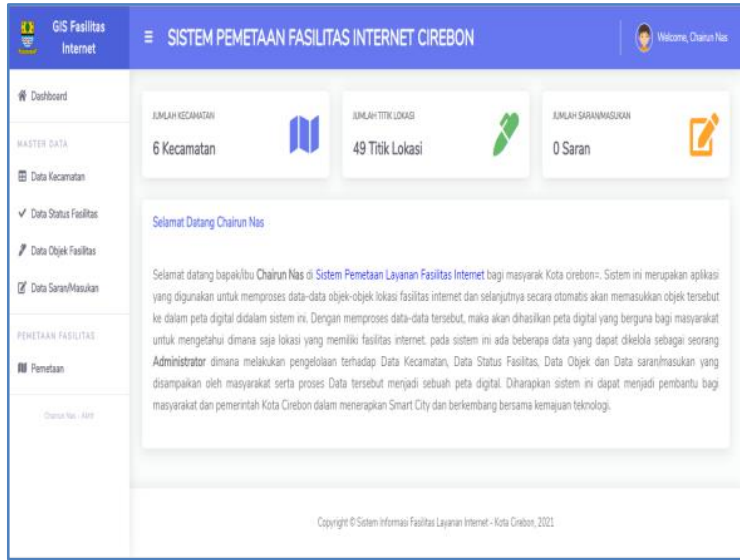

Figure 10. Admin Main page 
3.2. District Data Management Page

District Data Management page is a page used by administrators to manage sub-district data and manage maps by sub-district. The display of the sub-district data management page can be seen in Figure 11 below:

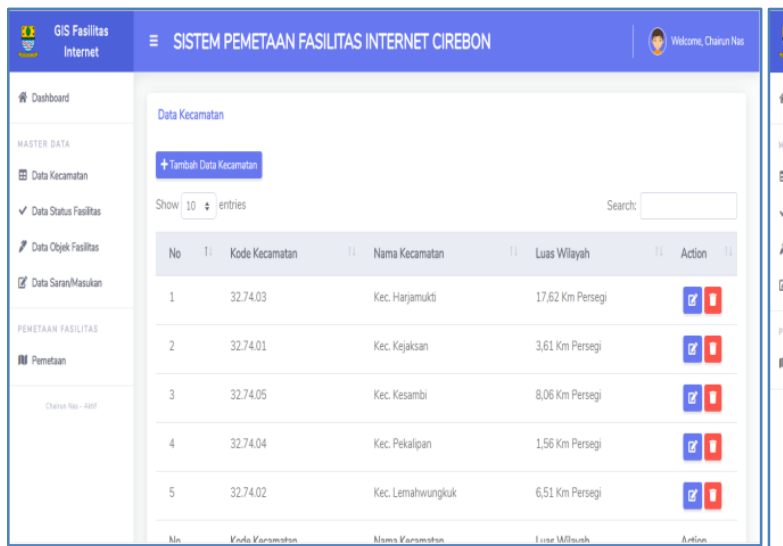

(a)

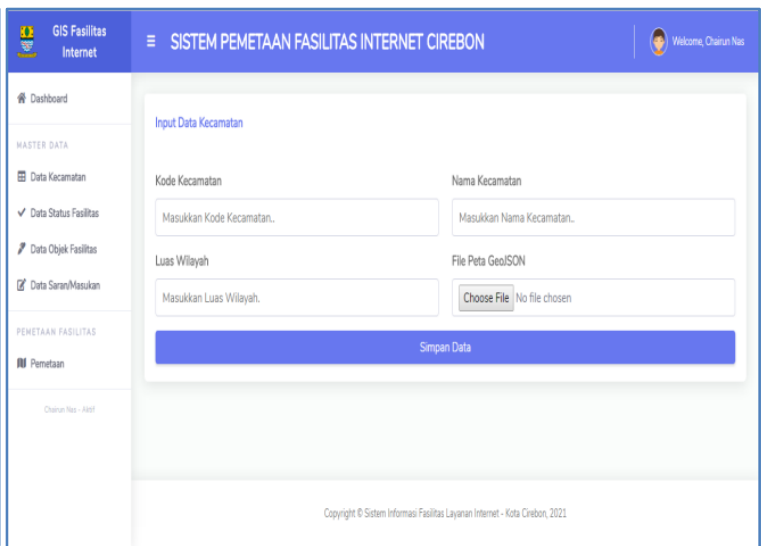

(b)

Figure 11. (a) Subdistrict Data Management Page, (b) Subdistrict Data Input Page

3.3. Object Data Management Page

Manage Object Data page is a page used by administrators to manage object data for internet facilities in Cirebon. The display of object data management page can be seen in Figure 12 below:

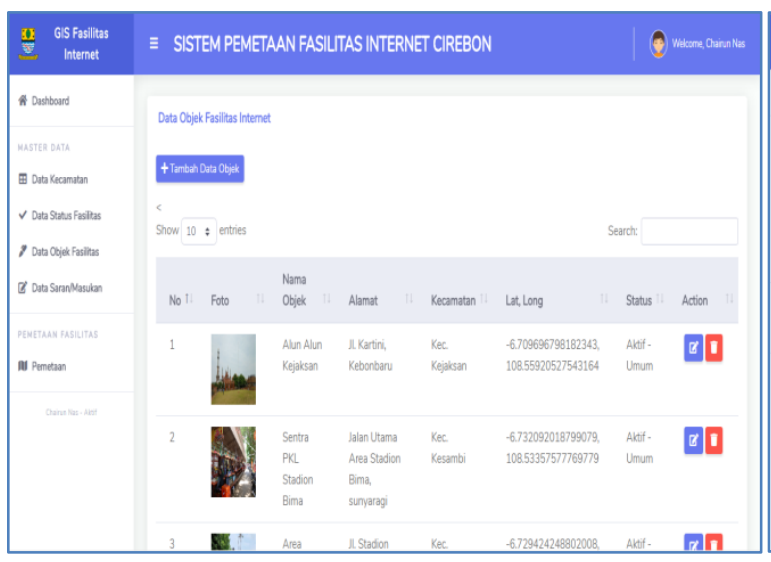

(a)

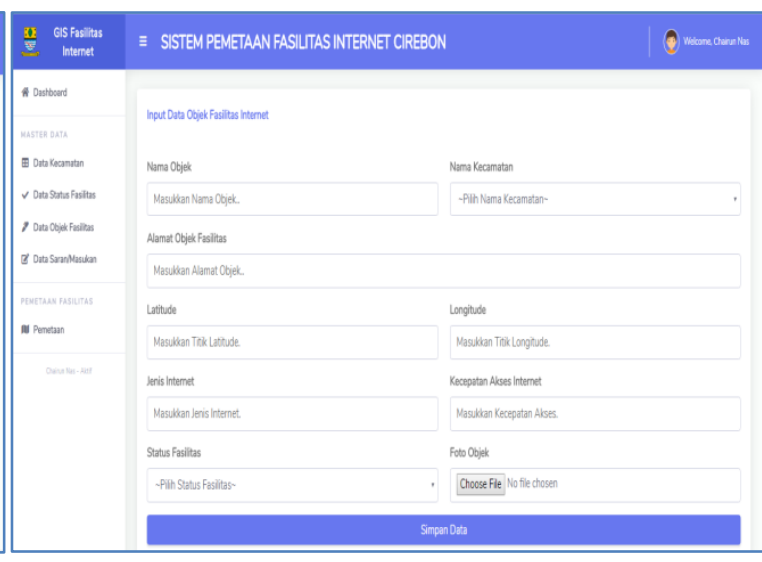

(b)

Figure 12. (a) Object Data Management Page, (b) Object Data Input Page

3.4. General User Page \& Object Information Pages

General User Page is a page used by general users for menus on the system. Object information page is used to view object information. The general user page display and Object information page can be seen in Figure 13 below: 


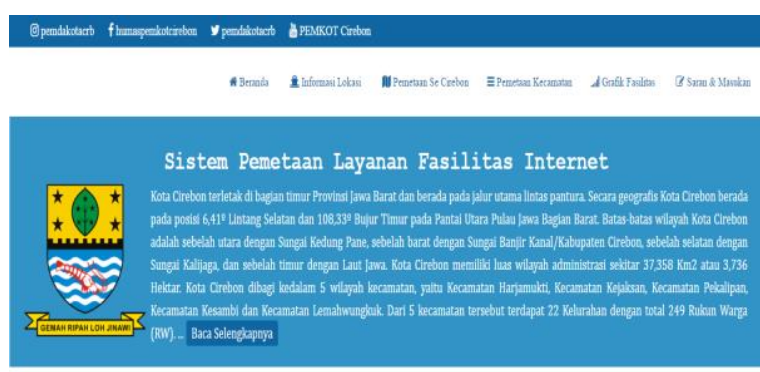

Informasi Layanan Fasilitas Internet

(a)

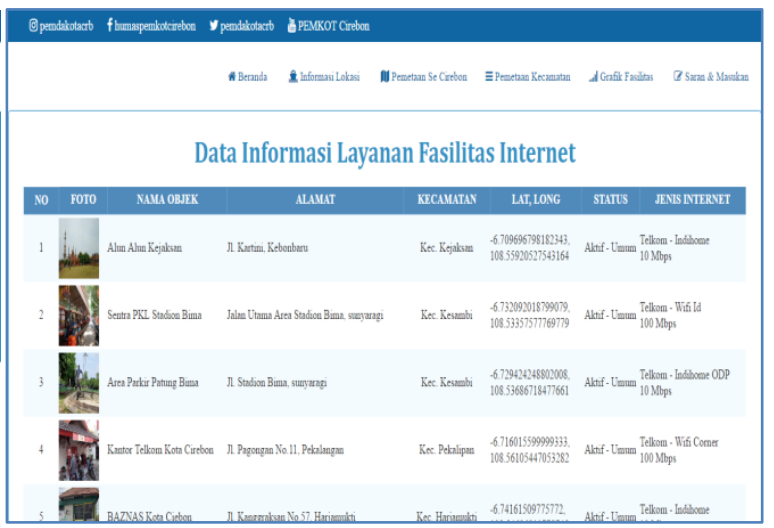

(b)

Figure 13. (a) General User Page, (b) Object Information Page

\subsection{Mapping Page \& Mapping Page Per District}

Mapping page is a page used by user to view location points of internet facilities in Cirebon. Mapping per sub-district is a mapping based on the sub-district. The display of mapping page and mapping per sub-district can be seen in Figure 14 below:

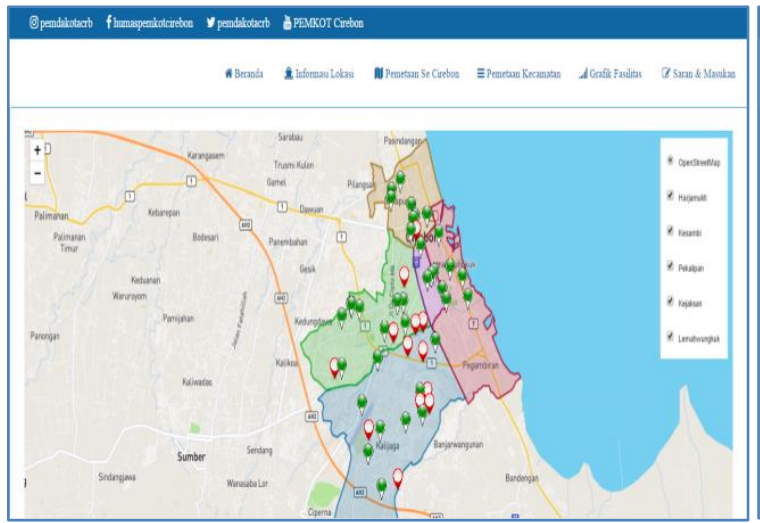

(a)

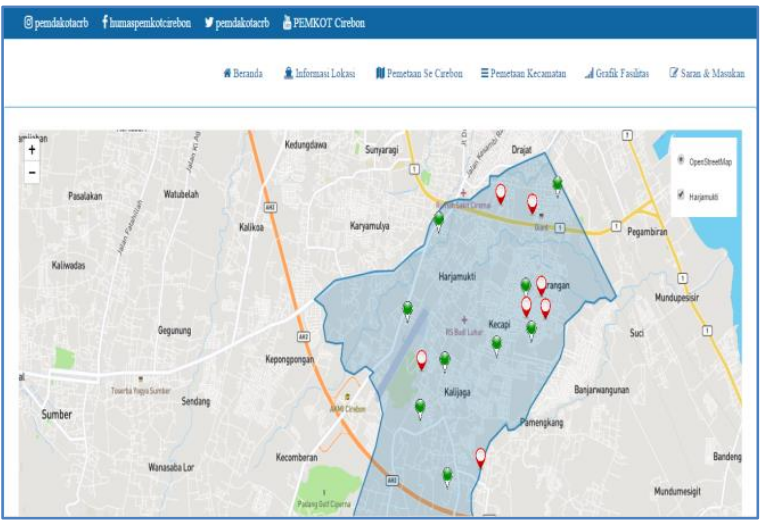

(b)

Figure 14. (a) Mapping Pages Cirebon, (b) Mapping Pages Per District

3.6. Mapping Location Point Information Details Page

Mapping location point information detail page is a page used by user to view detailed information about the location points on the map. The detailed display of mapping location point information can be seen in Figure 15 below:
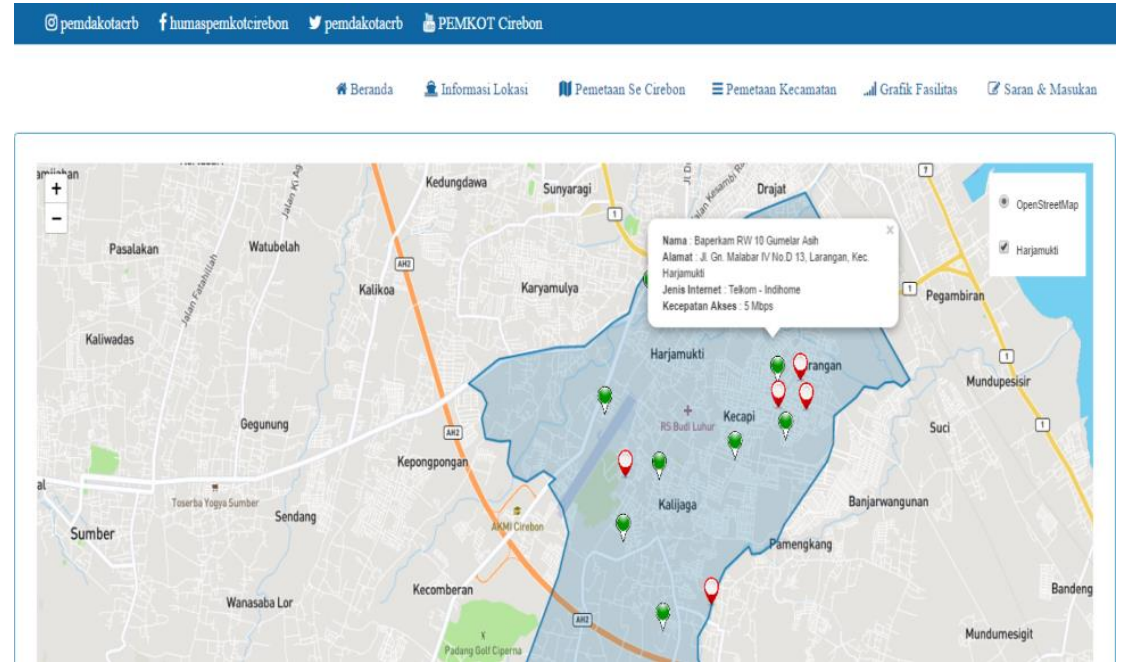

Figure 15. Mapping location point information detail page 
The results of the development of geographic information system mapping location of Cirebon internet facility service can already be functioned properly and make public easier for to find out location points of internet facilities in Cirebon.

\section{c. Conclusion}

Based on the research was conducted, it has been resulted that by using NNA algorithm analysis of 49 location point data, the distribution pattern of location points internet facilities in Cirebon is $60 \%$ evenly distributed and $40 \%$ randomly distributed. The results of this analysis can assist the government in making future decisions for location point in the implementation of internet facilities in Cirebon. Furthermore, by mapping using GeoJSON and implementing mapping using Leaflet JS, a website-based geographic information system is produced that can be used by public to be able to view information about location of internet facilities in Cirebon anytime and anywhere as long as they have internet access and platforms.

\section{References}

[1] C.E.W. Utomo and M. Hariadi, " Strategi Pembangunan Smart City dan Tantangannya bagi Masyarakat Kota," Jurnal Strategi dan Bisnis, vol. 4, no.2, pp. 159-176, 2016.

[2] A.A. Zabar dan F. Novianto, " Keamanan Http Dan Https Berbasis Web Menggunakan Sistem Operasi Kali Linux," Jurnal Ilmiah Komputer dan Informatika, vol. 4, no.2, pp. 69-74, 2015.

[3] Mukhlis and L. Harudu, " Pola Persebaran Dan Keterjangkauan Lokasi Sekolah Terhadap Pemukiman Dengan Menggunakan Sistem Informasi Geografis Kecamatan Batuga Kabupaten Buton Selatan," Jurnal Penelitian Pendidikan Geografi, vol. 4, no.4, pp. 01-08, 2019.

[4] B. Ahaliki, " Sistem Informasi Geografis (SIG) Pemetaan Dan Analisis Daerah Pertahan Di Kabupaten Gorontalo," JTECH, vol. 4, no.2, pp. 116-122, 2016.

[5] N. Awaliah, N. Latif and Markani, " Implementasi Sistem Informasi Geografis Layanan Publik Lingkup Kota Parepare Berbasis Web," Jurnal Ilmiah Ilmu Komputer, vol. 6, no.2, pp. 55-59, 2020.

[6] D. Hamdani and T.S. Virgana, " Implementasi Sistem Informasi Geografis untuk Pemetaan Sebaran Jumlah Penduduk di Kota Cimahi," Jurnal Manajemen Informatika, vol. 10, no. 2, pp. 161-170, 2020.

[7] C. Nas and W. Ilham, " Mapping Leading Local Culture Of Cirebon Tourism Sector Using Geographic Information System (GIS)," Jurnal Teknologi dan Open Source, vol. 4, no. 1, pp. 19-27, 2021.

[8] J.A.D. Pujayanti, B. Susilo and D. Puspitaningrum, " Sistem Informasi Geografis Untuk Analisis Persebaran Pelayanan Kesehatan Di Kota Bengkulu," Jurnal Rekursif, vol. 2, no. 2, pp. 99-111, 2014.

[9] W. Ibnu and M. Jazman, " Rancang Bangun Sistem Informasi Geogafis Pemetaan Ruang Ujian Menggunakan Bootstrap dan Leaflet.js," in SNTIKI 9. Pekan Baru 18-19 Mei 2017, pp. 257-264, 2017.

[10] Haviluddin, " Memahami Penggunaan UML (Unified Modelling Language)," Jurnal Informatika Mulawarman, vol. 6, no. 1, pp. 01-15, 2011.

[11] A. Hendini, " Pemodelan UML Sistem Informasi Monitoring Penjualan Dan Stok Barang," Jurnal Khatulistiwa Informatika, vol. 4, no. 2, pp. 107-116, 2016.

[12] W. Aprianti and U. Maliha, " Sistem Informasi Kepadatan Penduduk Kelurahan Atau Desa Studi Kasus Pada Kecamatan Bati-Bati Kabupaten Tanah Laut," Jurnal Sains dan Informatika, vol. 2, no. 1, pp. 21-28, 2016.

[13] T.B. Kurniwan and Syarifuddin, " Perancangan Sistem Aplikasi Pemesanan Makanan Dan Minuman Pada Cafetaria No Caffe Di Tanjung Balai Karimun Menggunakan Bahasa Pemrograman PHP \& MySQL," Jurnal Tikar, vol. 1, no. 2, pp. 192-206, 2020.

[14] J.T. Evan, R. Silvia and H. Andreas, " Pemetaan Surabaya Heritage Dengan Geographic Information System," Media Neliti, vol. 1, no. 1, pp. 01-04, 2013. 